НАУКОВИЙ ВІСНИК

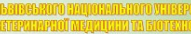

Gientific messenger of Lviv National University
Veterinary Meedicine and Bioteclinologies

nownon

DIIIY

Том 21 № 91

2019
Науковий вісник Дьвівського національного університету ветеринарної медицини та біотехнологій імені С.3. Гжицького. Серія: Сільськогосподарські науки

\author{
Scientific Messenger of Lviv National University
} of Veterinary Medicine and Biotechnologies. Series: Agricultural sciences

ISSN 2519-2698 print

https://nvlvet.com.ua/index.php/agriculture

doi: $10.32718 /$ nvlvet-a9113

UDC 636.2.034.082

\title{
Exterior special characteristics of cows and their descendants of different generations at high-producing herds
}

\author{
E.I. Fedorovych ${ }^{1}$, S.I. Fyl $1^{2}$, P.V. Bodnar ${ }^{3}$ \\ ${ }^{1}$ Institute of animal biology NAAS, Lviv, Ukraine \\ ${ }^{2}$ Institute of Animal Breeding and Genetics nd. a. M.V. Zubets of National Academy of Agrarian Science of Ukraine \\ ${ }^{3}$ Stepan Gzhytskyi National University of Veterinary Medicine and Biotechnologies Lviv, Ukraine
}

Article info

Received 11.09.2019

Received in revised form 14.10.2019

Accepted 15.10.2019

Institute of Animal Breeding and Genetics nd. a. M.V. Zubets of

National Academy of Agrarian

Science of Ukraine, Pohrebnyaka

Str., 1, Chubynske, Boryspil region

Kyiv district, 08321, Ukraine.

Institute of animal biology NAAS

Vasyl Stus Str., 38, Lviv,

79034, Ukraine.

Tel.: +38-032-270-23-89

E-mail:logir@ukr.net

Stepan Gzhytskyi National University of Veterinary Medicine and Biotechnologies Lviv,

Pekarska Str., 50, Lviv,

79010, Ukraine.
Fedorovych, E.I., Fyl, S.I., \& Bodnar, P.V. (2019). Exterior special characteristics of cows and their descendants of different generations at high-producing herds. Scientific Messenger of Lviv National University of Veterinary Medicine and Biotechnologies. Series: Agricultural sciences, 21(91), 76-82. doi: 10.32718/nvlvet-a9113

The results of studies of the exterior characteristics of first-calf cows and their descendants of different generations are presented. The studies were conducted at high-producing herds (average yields per a cow about $10000 \mathrm{~kg}$ ) LLC "Veleten" of the Glukhiv district of Sumy region and PJSC "Plemzavod "Stepnoy" of the Kamyansko-Dniprovskyy district of Zaporizhzhya region created out of the absorption crossing of the Ukrainian Black-and-White dairy breed females with Holstein breeders, first-calf cows and their descendants of the first, second, and at PJSC "Plemzavod "Stepnoy" - also of third generations. The sample of animals includes $62.5-100 \%$ share of Holstein inheritance. There was some differentiation between the cows of the controlled herds according to the investigated body measurements: the first-calf cows of PJSC "Plemzavod "Stepnoy" were highly dominated the herdmates of LLC "Veleten" by height at the withers by 3.2, chest depth by 1.4, chest girth by the shoulder by 1.2 and oblique body length - by 1.7 $\mathrm{cm}$, but were inferior to them in chest width by $0.8(P<0.05)$, width of oysters - by 0.4 and girth of wristby $0.3 \mathrm{~cm}(P<0.001)$. The cows of both farms, by all studied exterior characteristics, outweighed their descendants of different generations, which is explained by the lower age of first calving for daughters, grandchildren and great-grandchildren than the cows from which they came. However, such a slight, although in most cases, probable differentiation between the exterior features of the cows and their descendants of the above generations appears to be the result of a better level of animal production of each successive generation, as indicated by their milk yields for the first lactation. However, according to all the investigated measurements (exception - width of oysters of cows of all generations and girth of wrist in the descendants of the second and third generations) animals of both controlled herds outperformed the target parameters of exterior characteristics for the first-calf cows of the desired type of Ukrainian Black-andWhite dairy breed. The analysis of body structure indices shows that the first-calf cows under control and their descendants of different generations were characterized by the type of body structure characteristic of dairy cattle. Between the body measurements of animals and their descendants of different generations, different strengths and directions of communication are established. The correlation coefficients between the exterior characteristics of cows and their daughters in LLC "Veleten", depending on the size, were in the range $-0.05-+0.15$, in cows and their granddaughters, within $-0.15-+0.06$, and the regression coefficients are within $-0.05-+0.19$ and $-0.15-+0.05$, respectively. In PJSC "Plemzavod "Stepnoy" the relative variability of body measurements in cows and their descendants of the first, second and third generations was $-0.07-+0.23$, respectively; $-0.19-+0.14$ and $-0.33-+0.26$, and regression coefficients ranged from -0.04 to +0.14 ; from -0.17 to +0.07 and from -0.47 to +0.16 . It should be noted that in both farms the correlation coefficients between the exterior features of animals of different generations were by no means probable, and the regression coefficients were only reliable between the chest depth behind the shoulders of cows and their daughters in LLC "Velyten" and between heights in the cows' hedge and their great-grandchildren at PJSC "Plemzavod "Stepnoy".

Key words: body measurements, body structure indices, first-calf cows, daughters, granddaughters, great-grandchildren, correlation coefficients, regression coefficients. 


\title{
Екстер'єрні особливості корів та їх потомків різних генерацій у високопродуктивних стадах
}

\author{
Є.І. Федорович ${ }^{1}$, С.І. Филь ${ }^{2}$, П.В. Боднар ${ }^{3}$ \\ ${ }^{1}$ Інститут біології тварин НААН, м. Львів, Україна \\ ${ }^{2}$ Інститут розведення і генетики тварин імені М.В. Зубия НААН, с. Чубинське, Украйна \\ ${ }^{3}$ Львівський національний університет ветеринарної медицини та біотехнологій імені С.3. Гәсицького, м. Львів, \\ Україна
}

\begin{abstract}
Наведено результати досліджень ознак екстер'єру корів-первісток та їх потомків різних генерацій. Дослідження проведені у високопродуктивних стадах (середній надій на корову близько 10000 кг) ТОВ “Велетень” Глухівського району Сумської області та ПАТ “Племзавод “Степной” Кам'янсько-Дніпровського району Запорізької області, створених за поглинального схрещування маток української чорно-рябої молочної породи з голштинськими плідниками, на коровах-первістках та їх нащадках першого, другого, а в ПАТ “Племзавод “Стєпной” - ще й третього поколінь У вибірку ввійшли тварини з часткою спадковості голштинів 62,5-100\%. Між коровами підконтрольних стад за досліджуваними промірами тіла спостерігалася певна диференціація: первістки ПАТ “Племзавод “Стєпной” високовірогідно переважали ровесниць ТОВ “Велетень” за висотою в холиі на 3,2, глибиною грудей - на 1,4, обхватом грудей за лопатками - на 1,2 та косою довжиною тулуба - на 1,7 см, однак поступалися ӥм за шириною грудей на 0,8 (P<0,05), шириною в маклаках - на 0,4 та обхватом п'ястка - на 0,3 см (P<0,001). Корови обох господарств за всіма досліджуваними ознаками екстер 'єру переважали своїх потомків різних генерацій, щзо пояснюється мениим віком першого отелення у дочок, онучок та правнучок, ніж у корів, від яких вони походили. Проте така незначна, хоча у більшості випадків $i$ вірогідна диференціація між ознаками екстер'єру у корів та їх потомків вищезазначених генерацій, мабуть, є результатом кращого рівня вирошування тварин кожного наступного покоління, на щзо вказують їхні надої за периу лактацію. Втім, за всіма досліджуваними промірами (виняток- ширина в маклаках у корів усіх генерачій та обхват п'ястка у потомків другого й третього поколінь) тварини обох підконтрольних стад переважали иільові параметри ознак екстер'єру для корів-первісток бажаного типу украӥнської чорно-рябої молочної породи. Аналіз індексів будови тіла свідчить, щзо корови-первістки підконтрольних стад та їх потомки різних генерачій відзначалися характерним для молочної худоби типом будови тіла. Між промірами тіла тварин та їх потомків різних поколінь встановлені різної сили та напряму зв 'язки. Коефіцієнти кореляції між ознаками екстер'єру корів та їх дочок у ТОВ “Велетень”, залежно від проміру, перебували в межах -0,05- +0,15, у корів та ї онучок - в межах -0,15- +0,06, а коефіцієнти регресії - відповідно в межах -0,05 - +0,19 та -0,15 - +0,05. У ПАТ “Племзавод “Стєпной”” співвідносна мінливість промірів тіла у корів та їх потомків першого, другого й третього поколінь становила відповідно -0,07 - +0,23; -0,19- +0,14 та -0,33 - +0,26, а коефіцієнти регресії коливалися від -0,04 до +0,14; від -0,17 до +0,07 та від -0,47 до +0,16. Варто зазначити, шүо у тварин обох господарств коефіцієнти кореляції між ознаками екстер'єру тварин різних генерацій у жодному випадку не були вірогідними, а коефічієнти регресї достовірними були лише між проміром обхвату грудей за лопатками у корів та їх дочок у ТОВ “Велетень” та між проміром висоти в холиі корів та їх правнучок у ПАТ “Племзавод “Стєпной”,".
\end{abstract}

Ключові слова: проміри тіла, індекси будови тіла, корови-первістки, дочки, онучки, правнучки, коефіцієнти кореляції, коефіцієнти регресї.

\section{Вступ}

Важливою складовою у комплексній системі селекції молочної худоби є оцінка та добір тварин за зовнішніми формами і пропорціями будови тіла (Zavadilová et al., 2011; Prokhorenko, 2013). Характеристика зовнішніх форм будови тіла тварин дає можливість виявити недоліки і вади екстер'єру, встановити відмінності за зовнішнім виглядом між окремими групами тварин, виділити бажаний тип для спрямованого добору та підбору (Klopenko et al., 2018), отримати уявлення про конституціональну міцність, здоров'я організму, про відповідність його тим умовам, у яких він існує, і в зв'язку з тією основною продуктивністю, заради якої цих тварин розводять (Fedorovych, 2015).

Практикою країн з розвиненим молочним скотарством доведено, що кращі за екстер'єрними якостями тварини зазвичай характеризуються високою молочною продуктивністю, доброю відтворною здатністю та продуктивним довголіттям (Prahov et al., 2010; Stoljar, 2011; Fedorovych, 2015; Poslavska et al., 2016).

Існуюча мінливість успадковуваності ознак екстер'єру мотивує необхідність постійного генетичного моніторингу селекційних стад за іiі ступенем (Khmelnychiyi, 2018).
3 огляду на зазначене, метою наших досліджень було вивчити екстер'єр корів-первісток різних генерацій у високопродуктивних стадах чорно-рябої худоби.

\section{Матеріал і методи досліджень}

Дослідження проведені у високопродуктивних стадах (середній надій на корову близько 10000 кг) ТОВ “Велетень” Глухівського району Сумської області та ПАТ "Племзавод "Стєпной” Кам'янськоДніпровського району Запорізької області, створених за поглинального схрещування маток української чорно-рябої молочної породи з голштинськими плідниками, на коровах-первістках та їх нащадках першого, другого, а в ПАТ “Племзавод “Стєпной” - ще й третього поколінь У вибірку ввійшли тварини з часткою спадковості голштинів 62,5-100\%.

Екстер'єр первісток оцінювали за даними зоотехнічного обліку та результатами власних досліджень. При цьому враховували такі проміри тіла: висота в холці, глибина грудей, ширина грудей, обхват грудей за лопатками, коса довжина тулуба (палицею), ширина в маклаках (клубах), обхват п’ястка. Шляхом співвідношення відповідних промірів вираховували індекси будови тіла тварин (Sirackyj et al., 2001). 
Для визначення характеру, напряму і величини зв'язку промірів тіла у корів та їх потомків різних генерацій обчислювали коефіцієнти кореляції (r) та регресії (R) за загальновідомими формулами.

Статистичну обробку даних здійснювали за допомогою програмного пакету Microsoft Excel за Г.Ф. Лакіним (Lakyn, 1990). Різницю між середніми значеннями вважали статистично вірогідною при $\mathrm{P}<$ $0,05\left(^{*}\right), \mathrm{P}<0,01\left(^{* *}\right), \mathrm{P}<0,001\left(^{* * *}\right)$.

Таблиця 1

Проміри тіла корів-первісток у підконтрольних стадах

\section{Результати та їх обговорення}

Аналіз екстер'єрних особливостей корів-первісток у підконтрольних стадах свідчить, що піддослідні тварини мали характерний для молочної худоби тип будови тіла (табл. 1). Водночас за досліджуваними промірами між ними спостерігалася певна диференціація. Так, первістки ПАТ “Племзавод “Стєпной” високовірогідно переважали ровесниць ТОВ “Велетень” за висотою в холці на 3,2, глибиною грудей - на 1,4, обхватом грудей за лопатками - на 1,2 та косою довжиною тулуба - на 1,7 cм, однак поступалися їм за шириною грудей на 0,8 (Р $<0,05)$, шириною в маклаках - на 0,4 та обхватом п'ястка - на 0,3 см $(\mathrm{P}<0,001)$.

\begin{tabular}{lcccc}
\hline \multirow{2}{*}{\multicolumn{1}{c}{ Назва проміру }} & ТОВ “Велетень” (n 302$)$ & ПАТ “Племзавод “Стєпной”” (n=284) \\
\cline { 2 - 5 } & $\mathrm{M} \pm \mathrm{m}$ & $\mathrm{Cv}, \%$ & $\mathrm{M} \pm \mathrm{m}$ & $\mathrm{Cv}, \%$ \\
\hline Висота в холці & $137,6 \pm 0,16$ & 2,0 & $140,8 \pm 0,12^{* * *}$ & 1,5 \\
Глибина грудей & $72,7 \pm 0,24$ & 5,7 & $74,1 \pm 0,20^{* * *}$ & 4,7 \\
Ширина грудей & $49,4 \pm 0,27$ & 9,6 & $48,6 \pm 0,24 *$ & 8,4 \\
Обхват грудей за лопатками & $195,8 \pm 0,29$ & 2,5 & $197,0 \pm 0,12$ & 1,0 \\
Коса довжина тулуба & $163,0 \pm 0,36$ & 3,9 & $164,7 \pm 0,21$ & 2,2 \\
Ширина в маклаках (клубах) & $50,7 \pm 0,21$ & 7,3 & $50,3 \pm 0,15$ & 5,1 \\
Обхват п’ястка & $18,4 \pm 0,03$ & 2,6 & $18,1 \pm 0,02 * * *$ & 2,3 \\
\hline
\end{tabular}

Успіх селекції корів за екстер'єром у молочному скотарстві, як свідчить практика зоотехнії, залежить від ступеня успадковуваності того чи іншого проміру тіла. Високий ступінь успадковуваності ознак екстер'єру, за умов цілеспрямованого добору й підбору тварин за екстер'єрним типом, дозволяє прискорити селекційний прогрес. Результати досліджень свідчать, що потомки піддослідних корів у ТОВ "Велетень" поступалися їм за всіма досліджуваними промірами (табл. 2). Так, дочки поступалися своїм матерям за висотою в холці на 1,0 ( $<<0,01)$, а онучки - на 0,4 см, за глибиною грудей - відповідно на $1,5(\mathrm{P}<0,01)$ i 0,7 , за шириною грудей - на $1,4(\mathrm{P}<0,05)$ i 0,6 , за обхватом грудей за лопатками - на $4,1(\mathrm{P}<0,001)$ i 4,6 $(\mathrm{P}<0,001)$, за косою довжиною тулуба - на 4,5 $(\mathrm{P}<0,001)$ i 2,6 (P < 0,05), за шириною в маклаках на $1,6(\mathrm{P}<0,001)$ і 1,0 та за обхватом п'ястка - на 0,1 i $0,1 \mathrm{~cm}$.

\section{Таблиця 2}

Проміри тіла корів-первісток та їх потомків у ТОВ “Велетень”, $\mathrm{M} \pm \mathrm{m}$

\begin{tabular}{|c|c|c|c|c|}
\hline \multirow{2}{*}{ Назва проміру } & Корови & Дочки & Корови & Онучки \\
\hline & \multicolumn{2}{|c|}{$\mathrm{n}=121$} & \multicolumn{2}{|c|}{$\mathrm{n}=47$} \\
\hline Висота в холці & $138,2 \pm 0,24$ & $137,2 \pm 0,25^{* *}$ & $137,6 \pm 0,42$ & $137,2 \pm 0,44$ \\
\hline Глибина грудей & $73,6 \pm 0,40$ & $72,1 \pm 0,36^{* *}$ & $72,3 \pm 0,58$ & $71,6 \pm 0,60$ \\
\hline Ширина грудей & $50,2 \pm 0,38$ & $48,8 \pm 0,44 *$ & $48,8 \pm 0,46$ & $48,2 \pm 0,87$ \\
\hline Обхват грудей за лопатками & $198,4 \pm 0,34$ & $194,2 \pm 0,45^{* * *}$ & $197,4 \pm 0,58$ & $192,8 \pm 0,76^{* * *}$ \\
\hline Коса довжина тулуба & $165,7 \pm 0,53$ & $161,2 \pm 0,53 * * *$ & $163,1 \pm 0,83$ & $160,5 \pm 0,95^{*}$ \\
\hline Ширина в маклаках & $51,7 \pm 0,29$ & $50,1 \pm 0,36^{* * *}$ & $50,7 \pm 0,38$ & $49,7 \pm 0,59$ \\
\hline Обхват п'ястка & $18,2 \pm 0,04$ & $18,1 \pm 0,04$ & $18,0 \pm 0,08$ & $17,9 \pm 0,07$ \\
\hline
\end{tabular}

Втім, варто зазначити, що менші показники промірів у потомків першої та другої генерації аж ніяк не свідчать про низьку успадковуваність ними ознак екстер'єру від матерів. Ця різниця пояснюється меншим віком першого отелення у дочок (25,3 місяця) та онучок (24,2 місяця), ніж у корів, від яких вони походили (30,7 і 29,9 місяця відповідно). Проте така незначна, хоча у більшості випадків і вірогідна диференціація між ознаками екстер'єру у корів та їх потомків вищезазначених генерацій, мабуть, є результатом кращого рівня вирощування тварин кожного наступного покоління, про що свідчать їхні надої за першу лактацію: у матерів - 6614 кг, у дочок - 8155 кг, в онучок - 8605 кг.

У ПАТ “Племзавод “Стєпной”” у первісток різних генерацій за ознаками екстер'єру спостерігалася подібна тенденція (табл. 3). Дочки поступалися матерям за висотою в холці на 0,9 (Р $<0,01)$, за глибиною грудей - на 1,0, за шириною грудей - на 3,3 (P < 0,001), за обхватом грудей за лопатками - на $0,9(\mathrm{P}<0,001)$, за косою довжиною тулуба - на 1,6 (P < 0,01), за шириною в маклаках - на 1,9 см $(\mathrm{P}<0,001)$ і лише за обхватом п'ястка різниці не виявлено. 
Таблиця 3

Проміри тіла корів-первісток та їх потомків у ПАТ “Племзавод “Стєпной”, $\mathrm{M} \pm \mathrm{m}$

\begin{tabular}{|c|c|c|c|c|c|c|}
\hline \multirow[t]{2}{*}{ Назва проміру } & Корови & Дочки & Корови & Онучки & Корови & Правнучки \\
\hline & \multicolumn{2}{|c|}{$\mathrm{n}=83$} & \multicolumn{2}{|c|}{$\mathrm{n}=58$} & \multicolumn{2}{|c|}{$\mathrm{n}=25$} \\
\hline Висота в холці & $141,4 \pm 0,21$ & $140,5 \pm 0,24^{* *}$ & $141,5 \pm 0,27$ & $140,8 \pm 0,26$ & $141,4 \pm 0,33$ & $140,1 \pm 0,46^{*}$ \\
\hline Глибина грудей & $74,8 \pm 0,53$ & $73,8 \pm 0,33$ & $75,4 \pm 0,56$ & $74,3 \pm 0,28$ & $75,3 \pm 0,63$ & $73,0 \pm 0,62^{* *}$ \\
\hline Ширина грудей & $50,9 \pm 0,68$ & $47,6 \pm 0,20^{* * * *}$ & $50,5 \pm 0,72$ & $48,4 \pm 0,42^{*}$ & $50,6 \pm 1,22$ & $47,1 \pm 0,52^{* *}$ \\
\hline Обхват грудей за лопатками & $197,0 \pm 0,18$ & $196,1 \pm 0,17^{* * *}$ & $197,0 \pm 0,22$ & $195,2 \pm 0,30^{* * *}$ & $196,6 \pm 0,37$ & $194,7 \pm 0,32^{* * *}$ \\
\hline Коса довжина тулуба & $164,8 \pm 0,45$ & $163,2 \pm 0,26^{* *}$ & $164,9 \pm 0,50$ & $161,7 \pm 0,52^{* *}$ & $164,5 \pm 0,69$ & $162,2 \pm 0,37^{* *}$ \\
\hline Ширина в маклаках & $51,6 \pm 0,40$ & $49,7 \pm 0,18^{* * *}$ & $51,7 \pm 0,46$ & $50,0 \pm 0,18^{* * *}$ & $51,3 \pm 0,65$ & $49,5 \pm 0,40^{*}$ \\
\hline Обхват п’ястка & $18,0 \pm 0,05$ & $18,0 \pm 0,04$ & $18,0 \pm 0,07$ & $17,9 \pm 0,06$ & $17,9 \pm 0,08$ & $17,8 \pm 0,11$ \\
\hline
\end{tabular}

Різниця між коровами та їх онучками за вищенаведеними ознаками екстер'єру становила відповідно 0,$7 ; 1,1 ; 2,1(\mathrm{P}<0,05), 1,8(\mathrm{P}<0,001), 3,2(\mathrm{P}<0,01)$, $1,7(\mathrm{P}<0,001)$ та $0,1 \mathrm{~cm}$, а між коровами і їх правнучками - 1,3 ( $\mathrm{P}<0,05), 2,3(\mathrm{P}<0,01), 3,5(\mathrm{P}<0,01), 1,9$ $(\mathrm{P}<0,001), 2,3(\mathrm{P}<0,01), 1,8(\mathrm{P}<0,05)$ та 0,1 см. Bapто відмітити, що найсуттєвіша різниця між коровами та їх нащадками наступних поколінь спостерігалася за шириною грудей та косою довжиною тулуба.

Втім, за всіма досліджуваними промірами (виняток - ширина в маклаках у корів усіх генерацій та обхват п'ястка у потомків другого й третього поколінь) тварини обох підконтрольних стад переважали цільові параметри ознак екстер'єру для корівпервісток бажаного типу української чорно-рябої молочної породи (Melnyk et al., 2003).
Оцінюючи екстер'єр молочної худоби за допомогою промірів тіла, не завжди можна охарактеризувати пропорційність та гармонійність розвитку організму тварин. Більш об'єктивно оцінити розвиток окремих статей, їх вікову мінливість, визначити тип будови тіла та вивчити їх зв'язок із напрямом і рівнем продуктивності тварин у певних господарських умовах можна, використавши співвідносне поєднання промірів, виражене у відносних одиницях індексів.

Встановлено, що корови-первістки підконтрольних стад відрізнялися між собою за індексами будови тіла (табл. 4). Однак за індексами довгоногості, збитості та вираженості типу, які характеризують не лише породні, але й типові та продуктивні якості тварин, різниця між ними була незначною і недостовірною. Значення цих індексів вказують на чітко виражений молочний тип піддослідних корів.

Таблиця 4

Індекси будови тіла корів-первісток у підконтрольних стадах

\begin{tabular}{|c|c|c|c|c|}
\hline \multirow{2}{*}{ Назва індексу } & \multicolumn{2}{|c|}{ ТОВ “Велетень” (n = 302) } & \multicolumn{2}{|c|}{ ПАТ “Племзавод “Стєпной”” (n = 284) } \\
\hline & $\mathrm{M} \pm \mathrm{m}, \%$ & $\mathrm{Cv}, \%$ & $\mathrm{M} \pm \mathrm{m}, \%$ & $\mathrm{Cv}, \%$ \\
\hline Довгоногості (високоногості) & $47,2 \pm 0,17$ & 6,2 & $47,4 \pm 0,15$ & 5,2 \\
\hline Розтягнутості (формату) & $118,5 \pm 0,27$ & 4,0 & $117,0 \pm 0,16^{* * *}$ & 2,4 \\
\hline Грудний & $68,0 \pm 0,37$ & 9,5 & $65,7 \pm 0,34^{* * *}$ & 8,8 \\
\hline Глибокогрудості & $52,8 \pm 0,17$ & 5,6 & $52,6 \pm 0,15$ & 4,6 \\
\hline Тазогрудний & $97,4 \pm 0,38$ & 6,8 & $96,6 \pm 0,37$ & 6,4 \\
\hline Широкогрудості & $35,9 \pm 0,20$ & 9,7 & $34,5 \pm 0,17^{* * *}$ & 8,2 \\
\hline Збитості (компактності) & $120,3 \pm 0,27$ & 3,8 & $120,6 \pm 0,18$ & 2,5 \\
\hline Костистості & $13,4 \pm 0,02$ & 3,3 & $12,9 \pm 0,02^{* * *}$ & 2,8 \\
\hline Масивності & $142,3 \pm 0,22$ & 2,7 & $139,9 \pm 0,15^{* * *}$ & 1,8 \\
\hline Масивності за Дюрстом & $58,8 \pm 0,52$ & 1,5 & $59,3 \pm 0,43$ & 1,2 \\
\hline Ейрисомії & $33,3 \pm 0,14$ & 7,4 & $32,4 \pm 0,11^{* * *}$ & 5,8 \\
\hline Лептосомії & $72,7 \pm 0,33$ & 7,9 & $70,2 \pm 0,25^{* * *}$ & 5,9 \\
\hline Вираженості типу & $23,6 \pm 0,13$ & 9,4 & $23,3 \pm 0,12^{*}$ & 8,3 \\
\hline Індекс статі & $103,1 \pm 0,37$ & 6,2 & $103,9 \pm 0,34$ & 5,5 \\
\hline Округлості ребер & $135,1 \pm 0,47$ & 6,0 & $132,9 \pm 0,41^{* * *}$ & 5,2 \\
\hline $\operatorname{yOT}^{1}(\mathrm{I})$ & $603,5 \pm 4,75$ & 13,7 & $626,1 \pm 3,50$ & 9,7 \\
\hline $\mathrm{YOT}^{1}(\mathrm{II})$ & $498,5 \pm 2,12$ & 7,4 & $508,9 \pm 0,88$ & 3,0 \\
\hline
\end{tabular}

Примітка: у цій і наступних таблицях: ${ }^{1}$ УОТ - умовний об’єм тулуба (за Ю. Полупаном)

На розвиток первісток піддослідних господарств у напрямку молочного типу вказують також невеликі значення індексу костистості (12,9-13,4\%).

Про гармонійність розвитку організму тварин, особливо у довжину, можна судити за індексом розтягнутості. За цим індексом первістки ТОВ "Велетень" високодостовірно переважали ровесниць ПАТ “Племзавод “Стєпной” на 2,7\%. Втім, його значення у тва- рин обох господарств також свідчать про їх розвиток у напрямку молочного типу.

Важливе значення для оцінки грудної клітки має застосування індексів, які характеризують ії розвиток, a саме: грудного, тазогрудного, ширикогрудості та глибокогрудості. Більшими значеннями цих індексів відзначалися тварини ТОВ “Велетень”, проте, це можна пояснити меншим віком отелення первісток у ПАТ “Племзавод “Стєпной”. 
Тварини підконтрольних стад відрізнялися між собою за індексами ейрисомії та лептосомії, значення яких свідчать, що корови першого господарства були більш широкотілими ніж другого. За індексами масивності та округлості ребер перевага була також на боці первісток ТОВ “Велетень”, а за індексами масивності за Дюрстом, округлості ребер, індексом статі та умовним об'ємом тулуба (за Ю. Полупаном I і II) уже на боці ровесниць ПАТ “Племзавод “Стєпной”.
Спостерігалася диференціація за досліджуваними індексами будови тіла і між коровами та їх потомками різних поколінь. У ТОВ “Велетень” дочки майже за всіма індексами поступалися матерям і лише за індексами довгоногості, збитості і тазогрудним - незначно переважали їх (табл. 5). Варто зазначити, що різниця між досліджуваними групами тварин була достовірною лише за індексами масивності, масивності за Дюрстом, лептосомії та умовним об'ємом тулуба (за Ю. Полупаном I і II).

\section{Таблиця 5}

Індекси будови тіла корів-первісток та їх потомків у ТОВ “Велетень”, \% (M \pm m)

\begin{tabular}{|c|c|c|c|c|}
\hline \multirow{2}{*}{ Назва індексу } & Корови & Дочки & Корови & Онучки \\
\hline & \multicolumn{2}{|c|}{$\mathrm{n}=121$} & \multicolumn{2}{|c|}{$\mathrm{n}=47$} \\
\hline Довгоногості & $46,8 \pm 0,29$ & $47,5 \pm 0,26$ & $47,4 \pm 0,41$ & $47,8 \pm 0,44$ \\
\hline Розтягнутості & $119,9 \pm 0,40$ & $117,5 \pm 0,40$ & $118,5 \pm 0,61$ & $117,1 \pm 0,84$ \\
\hline Грудний & $68,4 \pm 0,50$ & $67,9 \pm 0,64$ & $67,6 \pm 0,80$ & $67,3 \pm 1,22$ \\
\hline Глибокогрудості & $53,2 \pm 0,29$ & $52,5 \pm 0,26$ & $52,6 \pm 0,41$ & $52,2 \pm 0,44$ \\
\hline Тазогрудний & $97,1 \pm 0,43$ & $97,6 \pm 0,67$ & $96,2 \pm 0,66$ & $97,0 \pm 1,28$ \\
\hline Широкогрудості & $36,4 \pm 0,28$ & $35,6 \pm 0,33$ & $35,5 \pm 0,35$ & $35,1 \pm 0,63$ \\
\hline Збитості & $119,9 \pm 0,39$ & $120,6 \pm 0,42$ & $121,1 \pm 0,64$ & $120,3 \pm 0,89$ \\
\hline Костистості & $13,2 \pm 0,04$ & $13,2 \pm 0,04^{* * *}$ & $13,1 \pm 0,07$ & $13,1 \pm 0,07$ \\
\hline Масивності & $143,6 \pm 0,31$ & $141,6 \pm 0,34^{* * *}$ & $143,5 \pm 0,59$ & $140,6 \pm 0,62^{* * *}$ \\
\hline Масивності за Дюрстом & $61,5 \pm 0,86$ & $56,9 \pm 0,74^{* * *}$ & $57,7 \pm 0,90$ & $55,6 \pm 0,13$ \\
\hline Ейрисомії & $33,6 \pm 0,19$ & $33,2 \pm 0,24$ & $33,1 \pm 0,27$ & $32,9 \pm 0,45$ \\
\hline Лептосомії & $73,8 \pm 0,47$ & $72,1 \pm 0,55^{*}$ & $72,4 \pm 0,60$ & $71,4 \pm 0,97$ \\
\hline Вираженості типу & $23,8 \pm 0,16$ & $23,8 \pm 0,21$ & $23,5 \pm 0,24$ & $23,6 \pm 0,47$ \\
\hline Індекс статі & $103,2 \pm 0,45$ & $102,9 \pm 0,62$ & $104,2 \pm 0,76$ & $103,8 \pm 1,22$ \\
\hline Округлості ребер & $135,4 \pm 0,81$ & $135,1 \pm 0,72$ & $136,9 \pm 1,21$ & $135,0 \pm 1,15$ \\
\hline yOT (I) & $633,1 \pm 7,57$ & $584,3 \pm 7,15^{* * *}$ & $600,0 \pm 8,82$ & $573,2 \pm 11,13$ \\
\hline yOT (II) & $519,9 \pm 2,72$ & $484,5 \pm 3,15^{* * *}$ & $506,5 \pm 4,45$ & $475,5 \pm 4,76^{* * *}$ \\
\hline
\end{tabular}

Онучки майже за всіма індексами (виняток - індекси довгоногості, костистості, вираженості типу та тазогрудний) також поступалися піддослідним коровам, проте достовірна різниця була виявлена лише за індексом масивності та умовним об'ємом тулуба (за Ю. Полупаном II).

У ПАТ “Племзавод “Стєпной” потомки першої, другої та третьої генерацій поступалися піддослідним коровам за індексами розтягнутості, грудним, тазогрудним, глибокогрудості, широкогрудості, масивності за Дюрстом, ейрисомії, лептосомії, вираженості типу та умовним об'ємом тулуба (за Ю. Полупаном I і II) i переважали їх за індексами довгоногості, збитості, масивності та округлості ребер (табл. 6).

\section{Таблиця 6}

Індекси будови тіла корів-первісток та їх потомків у ПАТ “Племзавод “Стєпной”, \% (M \pm m)

\begin{tabular}{|c|c|c|c|c|c|c|}
\hline Назва проміру & Корови & Дочки & Корови & Онучки & Корови & Правнучки \\
\hline & \multicolumn{2}{|c|}{$\mathrm{n}=83$} & \multicolumn{2}{|c|}{$\mathrm{n}=58$} & \multicolumn{2}{|c|}{$\mathrm{n}=25$} \\
\hline Довгоногості & $47,1 \pm 0,38$ & $47,5 \pm 0,23$ & $46,7 \pm 0,40$ & $47,3 \pm 0,19$ & $46,7 \pm 0,44$ & $47,9 \pm 0,41^{*}$ \\
\hline Розтягнутості & $116,6 \pm 0,33$ & $116,2 \pm 0,24$ & $116,6 \pm 0,41$ & $114,8 \pm 0,38^{* *}$ & $116,3 \pm 0,52$ & $115,8 \pm 0,34$ \\
\hline Грудний & $68,2 \pm 0,92$ & $64,7 \pm 0,42^{* * *}$ & $67,0 \pm 0,72$ & $65,2 \pm 0,58^{*}$ & $67,1 \pm 1,26$ & $64,6 \pm 0,68$ \\
\hline Глибокогрудості & $52,9 \pm 0,38$ & $52,5 \pm 0,23$ & $53,3 \pm 0,40$ & $52,7 \pm 0,19$ & $53,3 \pm 0,44$ & $52,1 \pm 0,41^{*}$ \\
\hline Тазогрудний & $98,4 \pm 0,89$ & $95,9 \pm 0,35^{* *}$ & $97,6 \pm 0,88$ & $96,9 \pm 0,85$ & $98,6 \pm 1,89$ & $95,4 \pm 1,33$ \\
\hline Широкогрудості & $36,0 \pm 0,47$ & $33,9 \pm 0,13^{* *}$ & $35,7 \pm 0,49$ & $34,4 \pm 0,31^{*}$ & $35,8 \pm 0,83$ & $33,6 \pm 0,35^{*}$ \\
\hline Збитості & $119,6 \pm 0,36$ & $120,2 \pm 0,20$ & $119,5 \pm 0,38$ & $120,8 \pm 0,51^{*}$ & $119,6 \pm 0,54$ & $120,0 \pm 0,36$ \\
\hline Костистості & $12,7 \pm 0,04$ & $12,7 \pm 0,04$ & $12,7 \pm 0,06$ & $12,7 \pm 0,05$ & $12,7 \pm 0,08$ & $12,7 \pm 0,08$ \\
\hline Масивності & $139,4 \pm 0,22$ & $139,7 \pm 0,29$ & $139,3 \pm 0,26$ & $138,6 \pm 0,34$ & $139,1 \pm 0,40$ & $139,0 \pm 0,52$ \\
\hline Масивності за Дюрстом & $63,0 \pm 1,19$ & $57,4 \pm 0,45^{* * *}$ & $63,1 \pm 1,42$ & $58,2 \pm 6,23^{* *}$ & $63,0 \pm 0,21$ & $55,9 \pm 0,96^{* *}$ \\
\hline Ейрисомії & $33,5 \pm 0,32$ & $32,0 \pm 0,09^{* * *}$ & $33,3 \pm 0,34$ & $32,5 \pm 0,18^{*}$ & $33,3 \pm 0,53$ & $32,0 \pm 0,20^{*}$ \\
\hline Лептосомії & $72,5 \pm 0,71$ & $69,3 \pm 0,22^{* * *}$ & $72,2 \pm 0,77$ & $69,8 \pm 0,38^{* *}$ & $72,0 \pm 1,16$ & $69,0 \pm 0,47^{*}$ \\
\hline Вираженості типу & $24,2 \pm 0,32$ & $22,9 \pm 0,09^{* * *}$ & $24,0 \pm 0,32$ & $23,5 \pm 0,23$ & $24,1 \pm 0,57$ & $22,8 \pm 0,23^{*}$ \\
\hline Індекс статі & $102,1 \pm 0,71$ & $104,4 \pm 0,41^{* *}$ & $102,8 \pm 0,72$ & $103,6 \pm 0,68$ & $102,1 \pm 1,47$ & $105,4 \pm 1,67$ \\
\hline Округлості ребер & $132,3 \pm 1,06$ & $133,2 \pm 0,69$ & $131,1 \pm 1,06$ & $131,5 \pm 0,53$ & $130,8 \pm 1,15$ & $133,6 \pm 1,09$ \\
\hline yOT (I) & $638,9 \pm 9,55$ & $598,2 \pm 4,33^{* * *}$ & $600,7 \pm 4,44$ & $490,7 \pm 1,72^{* * *}$ & $637,4 \pm 15,51$ & $586,3 \pm 8,13^{* *}$ \\
\hline yOT (II) & $509,4 \pm 1,54$ & $499,9 \pm 1,27^{* * *}$ & $600,7 \pm 4,44$ & $490,7 \pm 1,72^{* * *}$ & $506,4 \pm 2,80$ & $489,5 \pm 1,78^{* * *}$ \\
\hline
\end{tabular}


Практикою зоотехнії доведено, що успіх селекції молочної худоби за екстер'єром значною мірою залежить від ступеня успадковуваності того чи іншого проміру тіла. Аналіз співвідносної мінливості промірів екстер'єру в підконтрольних первісток свідчить про різної сили та напряму зв'язки у корів та їх по- томків різних генерацій (табл. 7). Коефіцієнти кореляції між ознаками екстер'єру корів та їх дочок у ТОВ “Велетень”, залежно від проміру, перебували в межах $-0,05-+0,15$, у корів та їх онучок - в межах $-0,15-$ $+0,06$, а коефіцієнти регресії - відповідно в межах $-0,05-+0,19$ та $-0,15-+0,05$.

\section{Таблиця 7}

Коефіцієнти кореляції і регресії між промірами тіла корів-первісток та цими показниками їх потомків у ТОВ "Велетень"

\begin{tabular}{lcccc}
\hline \multicolumn{1}{c}{ Назва проміру } & \multicolumn{2}{c}{ Коефіціснти кореляції, $\mathrm{r} \pm \mathrm{m}_{\mathrm{r}}$} & \multicolumn{2}{c}{ Коефіцієнти регресії, $\mathrm{R} \pm \mathrm{mR}$} \\
\cline { 2 - 5 } & дочок $(\mathrm{n}=121)$ & онучок $(\mathrm{n}=47)$ & дочок $(\mathrm{n}=121)$ & онучок $(\mathrm{n}=47)$ \\
\hline Висота в холці & $0,14 \pm 0,089$ & $0,03 \pm 0,146$ & $0,14 \pm 0,089$ & $0,03 \pm 0,146$ \\
Глибина грудей & $0,15 \pm 0,089$ & $-0,15 \pm 0,143$ & $0,14 \pm 0,089$ & $-0,15 \pm 0,143$ \\
Ширина грудей & $0,13 \pm 0,089$ & $-0,05 \pm 0,145$ & $0,15 \pm 0,089$ & $-0,10 \pm 0,144$ \\
Обхват грудей за лопатками & $0,14 \pm 0,089$ & $-0,03 \pm 0,146$ & $0,19 \pm 0,088^{*}$ & $-0,04 \pm 0,146$ \\
Коса довжина тулуба & $0,01 \pm 0,091$ & $-0,08 \pm 0,145$ & $0,01 \pm 0,091$ & $-0,09 \pm 0,145$ \\
Ширина в маклаках & $0,02 \pm 0,091$ & $0,02 \pm 0,146$ & $0,03 \pm 0,091$ & $0,02 \pm 0,146$ \\
Обхват п’ястка & $-0,05 \pm 0,091$ & $0,06 \pm 0,145$ & $-0,05 \pm 0,091$ & $0,05 \pm 0,145$ \\
\hline
\end{tabular}

У ПАТ “Племзавод “Стєпной” співвідносна мінливість промірів тіла у корів та їх потомків першого, другого й третього поколінь становила відповідно
$-0,07-+0,23 ;-0,19-+0,14$ та $-0,33-+0,26$, а коефіцієнти регресії коливалися від $-0,04$ до $+0,14$; від $-0,17$ до +0,07 та від $-0,47$ до +0,16 (табл. 8).

\section{Таблиця 8}

Коефіцієнти кореляції і регресії між промірами тіла корів-первісток та цими показниками їх потомків у ПАТ "Племзавод "Стєпной”

\begin{tabular}{|c|c|c|c|c|c|c|}
\hline \multirow[b]{2}{*}{ Назва проміру } & \multicolumn{3}{|c|}{ Коефіцієнти кореляції, $\mathrm{r} \pm$ mr } & \multicolumn{3}{|c|}{ Коефіцієнти регресії, $\mathrm{R} \pm$ mR } \\
\hline & $\begin{array}{c}\text { дочок } \\
(\mathrm{n}=83)\end{array}$ & $\begin{array}{l}\text { онучок } \\
(\mathrm{n}=58)\end{array}$ & $\begin{array}{c}\text { правнучок } \\
(\mathrm{n}=25)\end{array}$ & $\begin{array}{c}\text { дочок } \\
(\mathrm{n}=83)\end{array}$ & $\begin{array}{l}\text { онучок } \\
(\mathrm{n}=58)\end{array}$ & $\begin{array}{c}\text { правнучок } \\
(\mathrm{n}=25)\end{array}$ \\
\hline Висота в холці & $0,02 \pm 0,110$ & $-0,18 \pm 0,127$ & $-0,33 \pm 0,197$ & $0,02 \pm 0,110$ & $-0,17 \pm 0,127$ & $-0,47 \pm 0,185^{*}$ \\
\hline Глибина грудей & $0,23 \pm 0,104$ & $0,14 \pm 0,129$ & $0,16 \pm 0,206$ & $0,14 \pm 0,108$ & $0,07 \pm 0,131$ & $0,15 \pm 0,206$ \\
\hline Ширина грудей & $0,04 \pm 0,110$ & $-0,10 \pm 0,130$ & $0,15 \pm 0,206$ & $0,01 \pm 0,110$ & $-0,06 \pm 0,131$ & $0,07 \pm 0,208$ \\
\hline Обхват грудей за лопатками & $0,11 \pm 0,109$ & $-0,01 \pm 0,131$ & $0,17 \pm 0,206$ & $0,10 \pm 0,109$ & $-0,01 \pm 0,131$ & $0,15 \pm 0,206$ \\
\hline Коса довжина тулуба & $-0,07 \pm 0,109$ & $0,02 \pm 0,131$ & $0,09 \pm 0,208$ & $-0,04 \pm 0,110$ & $0,02 \pm 0,131$ & $0,05 \pm 0,208$ \\
\hline Ширина в маклаках & $-0,02 \pm 0,110$ & $-0,19 \pm 0,127$ & $0,26 \pm 0,201$ & $-0,01 \pm 0,110$ & $-0,07 \pm 0,131$ & $0,16 \pm 0,206$ \\
\hline Обхват п’ястка & $-0,03 \pm 0,110$ & $-0,14 \pm 0,129$ & $-0,15 \pm 0,206$ & $-0,03 \pm 0,110$ & $-0,11 \pm 0,130$ & $-0,20 \pm 0,204$ \\
\hline
\end{tabular}

Варто зазначити, що у тварин обох господарств коефіцієнти кореляції між ознаками екстер'єру тварин різних генерацій у жодному випадку не були вірогідними, а коефіцієнти регресії достовірними були лише між проміром обхвату грудей за лопатками у корів та їх дочок у ТОВ “Велетень" та між проміром висоти в холці корів та їх правнучок у ПАТ “Племзавод “Стєпной”.

\section{Висновки}

1. Між коровами підконтрольних стад за досліджуваними промірами тіла спостерігалася певна диференціація: первістки ПАТ “Племзавод "Стєпной”", високовірогідно переважали ровесниць ТОВ "Велетень" за висотою в холці, глибиною грудей, обхватом грудей за лопатками та косою довжиною тулуба, однак поступалися їм за шириною грудей $(\mathrm{P}<0,05)$, шириною в маклаках та обхватом п'ястка $(\mathrm{P}<0,001)$.

2. Корови обох господарств за всіма досліджуваними ознаками екстер'єру переважали своїх потомків різних генерацій, що пояснюється меншим віком першого отелення у дочок, онучок та правнучок, ніж у корів, від яких вони походили. Проте така незначна, хоча у більшості випадків і вірогідна диференціація між ознаками екстер'єру у корів та їх потомків вищезазначених генерацій, мабуть, є результатом кращого рівня вирощування тварин кожного наступного покоління, на що вказують їхні надої за першу лактацію.

3. Аналіз індексів будови тіла свідчить, що корови-первістки підконтрольних стад та їх потомки різних генерацій відзначалися характерним для молочної худоби типом будови тіла.

4. Між ознаками екстер'єру в корів-первісток та їх потомків різних поколінь встановлені різної сили та напряму зв'язки, однак у жодному випадку вони не були вірогідними.

Перспективи подальших досліджень. У подальшому буде досліджено вплив ознак екстер'єру на формування молочної продуктивності у корів підконтрольних стад.

\section{References}

Fedorovych, V.V. (2015). Selekcijno-genetychni ta biologichni osoblyvosti tvaryn zavods'kyh i lokal'nyh 
molochnyh ta molochno-m'jasnyh porid hudoby $\mathrm{v}$ umovah zahidnogo regionu Ukrai'ny: dys... dokt. s.-g. nauk: scec. 06.02.01 "rozvedennja ta selekcija tvaryn", 455 (in Ukrainian).

Fedorovych, V.V. (2015). Zalezhnist' molochnoi' produktyvnosti koriv ukrai'ns'koi' chorno-rjaboi' molochnoi' porody vid promiriv i'h statej tila pislja pershogo otelennja. Visnyk Sums'kogo nacional'nogo

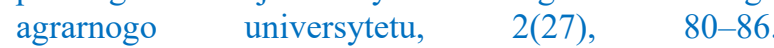
http://nbuv.gov.ua/UJRN/Vsna_tvar_2015_2_20 (in Ukrainian).

Khmelnychiyi, S.L. (2018). Uspadkovuvanist' statej ekster'jeru koriv sums'kogo vnutrishn'oporodnogo typu ukrai'ns'koi' chorno-rjaboi' molochnoi' porody. Aktual'ni pytannja tehnologii' produkcii' tvarynnyctva: Zbirnyk statej za rezul'tatamy III Vseukrai'ns'koi' naukovo-praktychnoi' internet-konferencii' 30-31 zhovtnja 2017 roku. Poltava, 57-62. https://www.pdaa.edu.ua/sites/default/files/academicd epartment/kafedra-harchovyh-

tehnologiy/zbirnykinternetkonfereciya20181.pdf\#page $=57$ (in Ukrainian).

Klopenko, N., Stavetska, R., Bushtruk, M., Starostenko, I., \& Babenko, O. (2018). Vplyv genotypnyh faktoriv na formuvannja gospodars'ko korysnyh oznak koriv ukrai'ns'koi' chorno-rjaboi' molochnoi' porody. Tehnologija vyrobnyctva i pererobky produkcii' tvarynnyctva: zbirnyk naukovyh prac', 2(145), 6-13. doi: $\quad 10.33245 / 2310-9289-2018-145-2-06-13$ (in Ukrainian).

Lakyn, H.F. (1990). Byometryia: uchebnoe posobye [dlia byol. spets. vuzov]. Moskow, Vysshaia shkola (in Russian).

Melnyk, Y.F., Mykytjuk, D.M., Pyshholka, V.A., Lytovchenko, A.M., $\quad$ Burkat, V.P., Bilous, O.V., Vyshnevskyi, L.V., Kurdrjavska, N.V., Pivinska, G.I., Gubin, O.O., Jefimenko, M.Ya., Antonenko, V.I.,
Gavrylenko, M.S., Kovalenko, G.S., Kuzmenko, I.I., Vasylkivskyi, S.B., $\quad$ Podoba, B.Je., Sirackij, Y.Z., Fedorovych, E.I., Sharan, P.I., Bashhenko, M.I., Tyshhenko, I.V., \& Khmelnychiyi, L.M. (2003). Programa selekcii' ukrai'ns'koi' chorno-rjaboi' molochnoi' porody velykoi' rogatoi' hudoby na 20032012 roky. Kyi'v, 83 (in Ukrainian).

Poslavska, Ju.V., Fedorovych, E.I., \& Bodnar, P.V. (2016). Vplyv ekster'jeru koriv-pervistok ukrai'ns'koi' chorno-rjaboi' molochnoi' porody na formuvannja i'h podal'shoi' molochnoi' produktyvnosti. Rozvedennja i genetyka tvaryn, 51, 131-139. http://digest.iabg.org.ua/images/digest/51/Animal_bre eding_and_genetics_51.pdf\#page=143 (in Ukrainian).

Prahov, L.P., Koval', L.L., \& Vorob'eva, N.V. (2010). Jekster'ernye osobennosti vysokoproduktivnyh korov. Zootehnija, 7, 12-13. https://elibrary.ru/ item.asp?id=15110746 (in Russian).

Prokhorenko, P. (2013). Golshtinskaja poroda i ee vlijanie na geneticheskij progres produktivnosti chornopestrogo skota evropejskih stran i Rossijskoj Federacii. Molochnoe i mjasnoe skotovodstvo, 2, 2-6. http://elibrary.ru/item.asp?id=18864999 (in Russian).

Sirackyj, Y.Z., Danylkiv, Ja.N., Danylkiv, O.M. ta in. (2001). Ekster'jer molochnyh koriv: perspektyvy ocinky i selekcii': monografija; za red. Y.Z. Sirackogo, E.I. Fedorovych. Kyi'v: Naukovyj svit (in Ukrainian).

Stoljar, Zh. (2011). Produktyvnist' koriv-pervistok zalezhno vid ekster'jeru ukrai'ns'koi' chorno-rjaboi' hudoby. Tvarynnyctvo Ukrai'ny, 3, 12-14 (in Ukrainian).

Zavadilová, L., Nemcová, E., \& Štípková, M. (2011). Effect of type traits on functional longevity of Czech Holstein cows estimated from a Cox proportional hazards model. Journal of Dairy Science, 94(8), 40904099. doi: 10.3168/jds.2010-3684. 